\title{
LITERARY MAGAZINE: ITS SOCIAL-AND-CULTURAL MISSION AND FUNCTIONS IN THE LITERARY COMMUNICATION
}

\author{
Olga G. Shilnikova \\ Volgograd State University, Volgograd, Russia \\ Galina S. Belolipskaya \\ Astrakhan State University, Astrakhan, Russia
}

\begin{abstract}
The article analyzes the functions of the literary magazine in the current social-and-cultural space. The educational, communicative, creative, social-and-cultural potential of modern monthly publications is revealed. It is stated that multifunctionality is one of the most valuable typological features of national literary magazines. Over a long period of Russian journalism, culture, and history development it was this specificity that ensured the stability of this type of media. At the same time, multifunctionality is the key to the further literary journal evolution as a publication type. In the article the objective and subjective causes of the modern journals crisis are determined. Due to the specificity of the content, literary publications face serious troubles in adapting to new social-and-cultural reality that is losing its artistic literary centricity and to the media product functioning aspects in the digital age, when literary communication takes on a altered quality and different forms. These circumstances largely determine the instability of the typological profile and the functional paradigm of modern magazines. A comprehensive way of overcoming crisis phenomena is proposed. It is proved that the future of literary magazines consists in integrationinto the new information reality and the new media system, while maintaining its unique cultural functionality. It is important that each publication concretizes its typological model: its mission, tasks, place in the cultural space, target audience; ideological and substantial vector of literary, critical, publicistic discourses and ways of their representation, structural features, authors, directions of extrajournalistic sociocultural activities.

Key words: literary magazine, context of a magazine, publication type, function of a magazine, cultural situation, literary and art communication, literary discourse, polydiscourse characteristics.

Citation. Shilnikova O.G., Belolipskaya G.S. Literary Magazine: Its Social-and-Cultural Mission and Functions in the Literary Communication. Vestnik Volgogradskogo gosudarstvennogo universiteta. Seriya 2. Yazykoznanie [Science Journal of Volgograd State University. Linguistics], 2019, vol. 18, no. 3, pp. 262-275. (in Russian). DOI: https://doi.org/10.15688/jvolsu2.2019.3.22
\end{abstract}

УДК 81 '42(051)

Дата поступления статьи: 10.06.2019

ББК 81.055 .51

Дата принятия статьи: 04.09.2019

\section{ЛИТЕРАТУРНО-ХУДОЖЕСТВЕННЫЙ ЖУРНАЛ: СОЦИОКУЛЬТУРНАЯ МИССИЯ И ФУНКЦИИ В ЛИТЕРАТУРНО-ХУДОЖЕСТВЕННОЙ КОММУНИКАЦИИ}

\author{
Ольга Геннадьевна Шильникова \\ Волгоградский государственный университет, г. Волгоград, Россия \\ Галина Сергеевна Белолипская \\ Астраханский государственный университет, г. Астрахань, Россия
}

Аннотация. В статье представлен анализ функций литературно-художественного журнала в актуальном социокультурном пространстве. Выявлен просветительский, коммуникативный, литературно-творческий, социокультурный потенциал современных ежемесячников. Показано, что полифункциональность - 
один из ценнейших типологических признаков отечественных журналов. В течение длительного периода развития российской журналистики, культуры, истории именно это качество во многом обеспечивало устойчивость данного типа СМИ. Одновременно полифункциональность - залог дальнейшей эволюции литературно-художественного журнала как типа издания. Определены объективные и субъективные причины кризиса современных журналов. Литературно-художественные издания в силу специфики их контента сложно адаптируются к теряющей литературоцентричность социокультурной реальности и особенностям функционирования медиапродуктов в цифровую эпоху, когда литературно-художественная коммуникация приобретает иное качество и иные формы. Названные обстоятельства во многом обусловливают неустойчивость типологического профиля и функциональной парадигмы журналов. В статье предложен путь преодоления кризисных явлений. Доказано, что будущее журналов в том, чтобы интегрироваться в новую информационную реальность и систему новых медиа, сохраняя свою уникальную культурную направленность. Важно, чтобы этот процесс сопровождался конкретизацией каждым изданием его типологической модели: миссии, задач, места в культурном пространстве, целевой аудитории, мировоззренческого и содержательного вектора художественного, критического, публицистического дискурсов и способов их репрезентации, структурных особенностей, авторского состава, направлений внежурнальной социокультурной деятельности.

Ключевые слова: литературно-художественный журнал, журнальный контекст, тип издания, функция журнала, культурная ситуация, литературно-художественная коммуникация, художественный дискурс, полидискурсивность.

Цитирование. Шильникова О. Г., Белолипская Г. С. Литературно-художественный журнал: социокультурная миссия и функции в литературно-художественной коммуникации // Вестник Волгоградского государственного университета. Серия 2, Языкознание. - 2019. - Т. 18, № 3. - C. 262-275. - DOI: https://doi.org/ 10.15688/jvolsu2.2019.3.22

\section{Введение}

О судьбе традиционного литературнохудожественного («толстого») журнала в России активно начали дискутировать с 1990-х гг., когда кризис переживала отечественная периодика в целом. Многим казалось, что перспектив у ежемесячника нет. За прошедшие годы положение журналов отчасти стабилизировалось. Однако вопрос об их дальнейшей судьбе остается открытым. «Журналы оказались в новой реальности. Это очень трудный, сложный и болезненный процесс - найти свое место в новой реальности, в новой России и вообще в этом веке», - справедливо заметил критик и редактор сетевой версии журнала «Новый мир» Сергей Костырко (цит. по: [«Толстяки на Урале»]).

Чтобы ответить на вопрос о перспективах «толстого» журнала, следует понять, какое место занимает этот социокультурный и эстетический феномен в жизни современной России. Есть ли те социальные и культурные сферы, где сохранилась потребность в изданиях подобного типа, какие обязанности они берут и могут взять на себя в актуальном социокультурном дискурсе, какие задачи способны решать. Другими словами, надо ответить на вопрос о функциях журна- ла - литературных, культурно-просветительских, социальных.

В научно-теоретическом аспекте исследование функциональной парадигмы современных журналов поможет в решении задач, связанных с определением оснований для дифференциации типологических вариантов литературно-художественных изданий как настоящего, так и прошлого.

Изучение исторической эволюции отечественного «толстого» журнала свидетельствует: в течение двухсот лет он формировался как издание полифункциональное, полидискурсивное, многоаспектное, динамическое в своих структурно-содержательных проявлениях. Отсюда следуют базовые принципы его исследования.

Поскольку журнал, в том числе современный, одновременно функционирует в нескольких сферах социальной реальности - литературной, культурно-просветительской, рекреативной, социальной, образовательной, и системе актуальных медиа, являясь неотъемлемой частью последних, он, несомненно, участвует (может участвовать) в их формировании, а значит, имеет несколько функциональных парадигм. Поэтому в процессе его научного осмысления следует использовать междисциплинарный подход - историко-журнали- 
стский, культурологический, филологический (в том числе и лингвистический), социологический. В данной статье приоритетными являются структурно-функциональный, типологический и культурологический анализ современных «толстых» журналов, а также метод научного прогнозирования. Последний базируется как на учете исторического опыта российских литературно-художественных журналов, так и на суждениях профессиональных литераторов и журналистов - критиков, редакторов, руководителей СМИ, имеющих серьезный издательский опыт и в настоящее время активно ищущих пути сохранени «толстого» журнала в современном информационнокоммуникативном пространстве в качестве авторитетного агента влияния на литературную и социокультурную ситуацию в России.

Комплексная задача настоящей статьи выявить реальные и потенциальные возможности современных литературно-художественных журналов, дать системный анализ причин их кризисного состояния в настоящий момент с учетом изменившихся социокультурных, экономических, технологических реалий информационного общества, наметить возможные пути выхода этих изданий на новый уровень.

\section{Функции «толстого» журнала в литературном процессе}

С конца прошлого столетия ведущие российские журналы стали активно позиционировать себя как защитники «вечных» духовных иееностей, хранители литературных традиций и высоких эстетических стандартов. В конце XX - начале XXI в. это было обусловлено рядом обстоятельств. Во-первых, журналы пытались найти свое место в стремительных переменах, происходивших в литературном процессе, среди которых пересмотр отношения к официальной литературе советского периода, «легализация» постмодернизма, необходимость определения статуса возвращенных писателей, лавинообразное наступление массовой «лотошной» (А.И. Солженицын) литературы, зачастую низкопробной, банальной, дурно влияющей на читательские вкусы. Во-вторых, ме- диапространство в целом переживало процессы структурного и качественного переформатирования. На рубеже веков шло бурное развитие журнально-газетного рынка, появлялось множество глянцевых еженедельников, привлекающих читателя новизной предлагаемого контента, порою почти маргинального, непривычными способами его репрезентации, яркостью оформления с акцентом на визуальном ряде. Для новой прессы была характерна мобильность реагирования на выходящую в свет художественную продукцию, оперативность ее подачи аудитории и одновременно неизбежная при издательском конвейере облегченность эстетических суждений о литератуpe, меньшая филологическая компетентность и авторов и критиков, поверхностность анализа артефактов. На этом фоне печатные версии «толстых» журналов действительно традиционно воспринимались читателями как более квалифицированные и вызывающие доверие литературно-эстетические издания.

Руководители современных журналов также справедливо подчеркивают их роль в качестве одного из экспертных каналов трансляции высоких гуманистических и художественных идеалов. До настоящего времени «уровень толстых журналов, качество публикуемых ими текстов не вызывает ни малейшего сомнения, они держат планку», - констатирует Дмитрий Бак [Бак, 2015].

Журналы все еще остаются «литературной формой», создающей оптимальные условия для культивирования и даже сохранения малых художественных, художественно-публииистических и литературно-критических жанров, которым трудно, а подчас и невозможно существовать в автономном режиме, - стихов, рассказов, очерков, эссе, рецензий, новелл.

Традиционное для литературной политики журналов внимание к малым жанровым формам отражает основные тенденции в области чтения современной аудитории. Культурологи, социологи, филологи фиксируют сдвиги читательских предпочтений от книги к текстам СМИ, трансформацию художественно-эстетических вкусов от больших жанровых форм к средним и малым. По данным Б.В. Дубина, «подавляющая часть сегодняшней публики, включая образованные слои рос- 
сиян среднего и старшего возраста, с середины 1990-х гг. перешла в чтении на жанровую и серийную словесность карманного масштаба» [Дубин, 2010, с. 71].

Чутко улавливают эту тенденцию и литературно-художественные журналы, на страницах которых современный читатель находит излюбленные малые художественные формы - рассказы, стихи, очерки, фельетоны, новеллы, пейзажные зарисовки, лирические миниатюры. Так, 10-й номер «Октября» за 2014 г. полностью был посвящен «короткой и свехкороткой» прозе. Культивируя коммерчески не окупаемые жанры, журналы не только следуют за читательской модой, но сохраняют и преумножают жанровую палитру отечественной словесности. Вспомним значение «толстых» журналов перестроечного периода в культивировании и кристаллизации жанра современного художественно-публицистического эссе, для публикации которых оперативно вводились специальные рубрики. В «Звезде» появилась «Эссеистика и критика», в «Дружбе народов» - «Эссе», в «Иностранной литературе» - «Статьи и эссе». В возрождении жанра проблемной литературно-критической статьи публицистического типа не меньшую роль сыграло «Знамя». «Наша задача... выпускать в свет и тем самым поддерживать заведомо некоммерческие явления в современной русской литературе. То есть стихи. То есть эссеистику. То есть малую прозу (рассказы, повести, etc.)», - заметил С. Чупринин уже в 2014 г. [Чупринин, 2014].

Пока еще нет равноценной альтернативы журналу в качестве своеобразной селекционной лаборатории, а также сцены для начинающих писателей, поэтов, публицистов. У него есть возможность участвовать в формировании достойной интеллектуальной и художественной элиты России. Литературно-художественный журнал, как правило, обладает авторитетом, имеет высокопрофессиональный кадровый состав. Для редколлегии экспертная оценка нового автора и артефакта (внутреннее рецензирование) является привычной и хорошо отработанной процедурой. В «толстых» журналах «с историей» работают те, кто хранит традиции высокопрофессиональной редактуры и культуры языка. «Мы и сейчас в основном поддерживаем и по- ощряем молодую литературу, а значит, эксперимент», - говорит главный редактор «Октября» Ирина Барметова [Барметова, 2017, с. 20].

Это направление деятельности журналов находит отражение не только в кропотливой предварительной работе с рукописями начинающих литераторов, но и в реальном журнальном контексте. Так, в «Знамени», одном из лучших современных журналов, есть рубрика «Карт-бланш», где литературные мэтры представляют начинающих авторов: Анатолий Курчаткин - Сергея Алтухова (2009. № 12), Владимир Маканин - Сергея Писщикова (2012. № 9), Вероника Долина - поэта Сергея Николаева (2015. № 7), Людмила Улицкая Настю Коваленкову (2015. № 8), Ольга Славникова - Нонну Гудиеву (2017. № 10), Сергей Чупринин - Ирину Турченко (2014. № 10). Страницы мартовского номера за 2019 г. редакция «Знамени» полностью предоставила молодым писателям, а вслед за тем организовала дискуссию на тему «Новое литературное поколение: существует ли оно?», результаты которой были опубликованы в очередном номере журнала (2019. № 6).

В современном интернет-пространстве реализуются разнообразные и достаточно эффективные и наглядные для массовой аудитории стратегии самопрезентации писателя, в том числе начинающего: паблисити, скайп-конференция, фотогалерея, автобиография, распространение имиджевых сведений, перепечатка положительных отзывов о своем творчестве, которые даны критиками, прессой, литературоведами, общественными структурами, организация собственных читательских форумов, тематических сообществ и многое другое [Анисимова, Ярова, 2011]. Однако квалифицированными читателями такие формы самопродвижения часто воспринимаются как слишком откровенный и не заслуживающий доверия пиар. Между тем блоги и сайты постоянных авторов, сопряженные с ведущими тенденциями редакционной политики того или иного журнала, могли бы стать органической частью его журнального интернет-проекта - сайта, портала, расширенной электронной версии.

Еще одна важная функция «толстого» ежемесячника - представлять панораму современной словесности в динамике, являя ее всегда мозаичный, ценностно нео- 
днородный и постоянно обновляющийся срез. Благодаря контексту, остросовременному и предельно погруженному в актуальную действительность, журнал имеет возможность воссоздавать полный, часто противоречивый образ текущего литературного процесса. Отсюда одна из тенденций литературной политики многих современных «толстых» журналов, отчетливо проявившаяся в постперестроечный период, - стремление к репрезентации художественного опыта представителей самых разных направлений, а также анализ и оценка крупномасштабных (тектонических) сдвигов в культурном поле, желание познакомить читателей с эстетическими инновациями, периферийными субкультурами, артефактами, находящимися на границе культурной и профанной сфер художественного творчества.

«Толстый» журнал, благодаря своей трехчастной структуре, включающей художественный, публицистический, литературно-критический модули и гибкую систему полидискурсивных рубрик и жанров, имеет возможность «максимально широко охватить современное книжное поле, воссоздать многообразие представленных в нем художественных жанров, видов, форм художественного творчества и, наконец, дает возможность продемонстрировать объективность проводимой литературной политики, широту подхода к освещению культурной жизни и даже эстетическую толерантность по отношению к “чужим” авторам» [Шильникова, 2011, с. 213].

Приведем авторитетное редакторское мнение Андрея Василевского. Он считает, что зеркалом литературного момента 2000-х гг. являлся не только художественный отдел журнала, где печатались новые тексты - стихи и проза, но также критические обзоры и рецензии. Основной принцип литературно-критической политики журнала в этот период главный редактор «Нового мира» формулировал так: «Печатать не все, а видеть, по возможности, все. Даже то, что нам несимпатично. И в этом, информационном, смысле "Новый мир" отличается от многих других журналов - по насыщенности упоминаниями, ссылками на другие издания, книги, публикации и т. д. Плюс рецензии, “книжные полки", обзоры» [Василевский, 2005]. А. Василевский считает необхо- димым «замечать, что у других происходит, отмечать даже маргинальные (или пока маргинальные) явления» [Василевский, 2005].

В последние несколько лет журнальная критика и редакционные коллективы в целом с энтузиазмом взялись за выполнение несколько забытой, но вполне конгениальной типологической природе «толстого» журнала задачи - аксиологическую дифференциацию $и$ ценностное моделирование современного художественного дискурса: «...у “толстых" журналов есть общая литературная стратегия. Они структурируют литературное пространство, просто принимая одни тексты к публикации и отказывая другим. Без журналов литературный мир сдвинулся бы в сторону Прозы.ру и Стихов.ру, а критику заменили блоги. Журнал вносит в литературу порядок, систему, иерархию. Так было и так будет», уверен заместитель главного редактора журнала «Урал» Сергей Беляков [Беляков, 2015].

Решение этой задачи осуществляется в разных организационных формах.

1. «Журналы непрерывно... поддерживают (развивают) традиции литературы в их разнообразии, содержательном, жанровом, стилистическом, языковом и... постоянно обновляют ее, меняют, преображают, ежемесячно вводят совсем новых авторов, привносящих в нее новые неожиданные произведения, новые парадоксальные по отношению к традиции тексты, а вместе с ними и новые смыслы» [Иванова, 2015].

2. Аксиологические функции выполняет традиционный для «толстого» журнала литературно-критический модуль с устойчивой и разнообразной системой оценочных жанров. Современные журнальные критики, как правило, не обременены коммерческими интересами. Дополнительный вес их оценочным суждениям придает авторитет журнала. Но главное в том, что продуцирование эстетических стандартов и критериев оценки художественного объекта - это и есть механизм работы литературно-критической рефлексии. Литературный аналитик вырабатывает критерии «для себя» в качестве операционного инструмента профессиональной деятельности. Однако выходя со своим мнением в публичное пространство, он тем самым предъявляет квалифицированную оценочную шкалу всему социуму. 
Поэтому деятельность журнальных критиков неизбежно формирует и поддерживает определенный уровень эстетического сознания общества, что в условиях тотального снижения художественных вкусов крайне важно не только для любителей чтения, но и для профессиональных участников литературно-художественной коммуникации и образовательной системы страны.

3. Оформились и стали авторитетными для авторов и востребованными у читателей такие виды аксиологической деятельности журналов, как присуждение литературных премий, комментирование решений премиальных комиссий, разъяснение и аргументация рейтинговых «листов», а в спорных случаях и выполнение роли общественного арбитра в проиессе обсуждения неоднозначных художественных явлений не только в литературе, но и в кино, живописи, театральном и музыкальном искусстве. В этом же ряду находятся весьма продуктивные дискуссии о состоянии современной словесности, регулярно проводимые ведущими российскими ежемесячниками.

Присуждение премий и связанная с этим организационная деятельность редакций один из наглядных для аудитории способов ценностного моделирования культурного пространства, помогающий читателям разобраться в иерархии крайне неоднородного в аксиологической плане современного книжного поля, в прагматическом аспекте - это форма поддержки писателей, возможный путь формирования репутации и продвижения автора.

Учредителями собственных литературных премий являются не только заслуженные столичные журналы - «Звезда», «Знамя», «Новый мир», «Октябрь, «Иностранная литература», но и региональные издания. Страницы 4-го номера «Знамени» за 2015 г. были полностью отданы произведениям авторов, которым с 1993 г. присуждалась премия журнала. В настоящее время это известные писатели, признанные и критикой, и читателями: Михаил Шишкин, Анатолий Курчаткин, Тимур Кибиров, Владимир Войнович, Сергей Гандлевский, Юрий Буйда, Марина Вишневецкая, Вячеслав Пьецух, Андрей Волос, Владимир Маканин, Александр Кабаков, Андрей Турков, Роман Сенчин, Олег Чухонцев,
Майя Кучерская, Алексей Слаповский, Александр Архангельский, Ольга Славникова. Всего более шестидесяти имен. Лауреатами премий «Знамени» в 2017 г. стали Марина Вишневецкая, Константин Куприянов, Ольга Славникова; в 2018 г. - Арина Обух, Владимир Орлов, Мария Рыбакова, Павел Селуков, Алексей Федяров. Орденов журнала за постоянное и плодотворное сотрудничество удостоены Денис Драгунский, Александр Кушнер.

4. В своем противостоянии массовой литературе и «аксиологическому нигилизму» в художественно-эстетической сфеpe журналы используют такой традиционный маркетинговый инструмент, как выпуск тематических и юбилейных номеров.

Раз в год выходит специальный номер «Звезды», целиком посвященный определенному культурному явлению: творчеству Анны Ахматовой, Марины Цветаевой, Владимира Набокова, Александра Солженицына, Иосифа Бродского, Сергея Довлатова, истории американской, немецкой, польской литературы. Спецпроект «Без таких городов не представить Россию» реализует воронежский «Подъем». Тематические выпуски-приложения последних лет связаны с литературой разных районов Воронежской области. Вышло уже более двух десятков таких номеров. Удачная творческая находка редакции «Знамени» - выпуск тематических номеров, посвященных значимым историческим вехами в жизни нашей страны. Это специальные номера «1917-2017», изданные к юбилею революции (2017. № 11), «Памяти Оттепели» (2018. № 8), которые были удостоены премии Российской государственной детской библиотеки «Память, говори».

Благодаря усилиям «толстых» журналов происходит формирование «синхронного самосознания» современных ежемесячников. В начале XXI в. судьба изданий данного типа оказалась в зоне внимания именно редакционных коллективов и журнальной литературной критики. Работа ведется в нескольких направлениях.

1. Публикация программных манифестов, интервью, организация опросов, дискуссий о роли, назначении, содержании, экономическом положении журналов (при активном содействии главных редакторов и журнальных аналитиков России). 
2. Участие в научных и общественных мероприятиях, где в том или ином ракурсе обсуждается состояние журнального поля. Так, летом 2015 г. в Москве прошел круглый стол «Журнальная Россия. История русской литературы XX века». В 2016 г. состоялся VI парламентский форум историко-культурного наследия России, где от Ассоциации литературных журналов выступала главный редактор «Октября» Ирина Барметова.

3. Организация собственных профессиональных форумов, на которых не только постоянно звучат вопросы о дальнейшей судьбе «толстого» журнала, о том, почему так затянулся переходный период журналов, а кризисные явления представляются почти непреодолимыми, но и происходит обмен позитивным опытом, налаживаются связи между столичными и региональными изданиями. В 2015 г. в Екатеринбурге состоялся первый фестиваль литературных журналов «Толстяки на Урале» в рамках объявленного в стране Года литературы. В мае 2018 г., в год 60летия «Урала» и под его эгидой, прошел четвертый такой фестиваль и круглый стол «Урал - опорный край журналов», где собрались главные редакторы ведущих «толстых» журналов страны и авторы этих изданий. В программе были литературные чтения, презентации книг, просмотр фильмов, снятых по произведениям, опубликованным в литературных журналах.

В каждом из перечисленных мероприятий задействованы все участники художественной коммуникации: редакторы, журналисты, критики, публицисты, писатели и читатели, общественные и властные структуры. Поэтому можно констатировать, что отечественные журналы стремятся выполнять важнейшую функцию форума, площадки, где благодаря обмену опьтом, смыслами, иенностями создаются условия для достижения консенсуса по вопросам художественно-эстетической и социокультурной жизни страны.

Хорошо известно, что в XIX и XX вв. журнальная публикация и критический отзыв во многом предопределяли писательский триумф или провал. И сейчас журнал в состоянии играть роль экспериментального полигона для книгоиздателей, желающих предвидеть, будет ли произведение пользоваться читательским спросом, и выяснить каким тиражом следует его издавать. По-прежнему в силах журнала создание устойчивой положительной (равно как и отрицательной) писательской penутации. По мнению критика и публициста Валентина Лукьянина, «толстые» журналы окончательно «из литературного обихода не вытеснены и на оставшемся под их контролем плацдарме продержатся... неопределенно долго. <..>. Дело в том, что сейчас они в области литературного творчества составляют главную и едва ли не единственную альтернативу рынку. То есть именно благодаря “толстым" журналам понятие литературного имени еще не вытеснено понятием "брэнда", а понятие художественной ценности - рейтингом продаж» [Лукьянин, 2005].

Художественные тексты в блоке с литературной критикой, эксплицируемые в журнальном контексте как «единое литературное событие» (В. Шкловский), - это проверенная временем и эффективная оптимальная модель «продвижения» произведения и автора. Однако с начала XXI в. появилось множество новых механизмов брендирования книги и форм продвижения писателя: рекламный коллаж, тартегинг, Ambient Media, буктрейлер, адверториал, мерчендайзинг, создание аудиокниг, виртуальных компьютерных игр [Анисимова, Ярова, 2011]. Проблема не в том, что PR-технологии соперничают с журналом и вытесняют его, а в том, что журналы могли бы включить рекламно-издательский инструментарий в арсенал работы со своей целевой аудиторией и авторами.

В условиях кардинальной качественной трансформации общества, культуры и медиапространства журналы стали консолидирующими центрами, в рамках которых активно формируется и развивается "синхронное самосознание» литературно-художественной критики. Эта крайне важная миссия оказалась периферийной и для массовой газетной, и для книжной, и для коммерческой, и тем более «Глянцевой» критики. Да и собственно концептуальная критическая аналитика традиционно остается прерогативой «толстых» журналов. Трудно не согласиться с мнением заместителя главного редактора журнала «Наш современник» Александром Казинцевым: «Профес- 
сиональный анализ может быть только в журнале. Не будет журналов, не будет критики. Не будет критики, не будет радостного открытия обществом новой литературы... и не будет, главное, тех критериев, которые вырабатывает критика, утверждают журналы и которые позволяют давать какую-то объективность. Не будет оценки, немыслимо будет и само творчество, оно не будет иметь никакой цены» (цит. по: [«Толстяки на Урале»]).

Разговор о самой критике, который ведут на страницах журналов лучшие и действующие представители профессии, всегда отличается глубиной, заинтересованностью, искренностью. Обсуждаемые вопросы о целях, задачах, аудитории, назначении в обществе, традиционных и новых форматах критического суждения для участников дискуссий являются не отвлеченными теоретическими конструктами, а требующими немедленного решения реальными проблемами. Свидетельство тому - два круглых стола, проведенные «Знаменем»: «Критика: последний призыв 1» (1999. № 12), «Критика: последний призыв 2» (2019. № 1).

Большинство участников дискуссии 2019 г. констатировали, что критика - «живой жанр литературы и журналистики» (Валерия Пустовая). В нее пришли молодые талантливые интеллектуалы, у которых есть профессиональный и личностный запрос на литературный диалог с аудиторией в пространстве художественного текста, на «развернутое аналитическое высказывание» (Борис Кутенков).

Между тем появление новых каналов литературной коммуникации изменило характер общения с аудиторией, форматы, временные рамки, жанрово-риторические характеристики критического высказывания. Сформировались новые векторы развития литературно-критического дискурса: книжная, блогерская, партиципаторная, коммерческая модели. Их роль и место в критическом модусе, соотношение с «традиционной» критикой не до конца прояснены, что и создает иллюзию кризиса.

«Толстожурнальная» критика «по-прежнему работает на порождение смыслов внутри литпроцесса, на его формирование в целом» [Подлубнова, 2019]. Однако, по мнению Галины Юзефович, она «сменила за последние тридцать лет свой статус - из массового чтения для более-менее образованных людей она превратилась в захватывающее интеллектуальное приключение для сравнительно немногочисленных истинных фанатов. Это значит, что теперь ей предстоит перепридумать себя, найти свое новое место, выработать методологию, поймать интонацию. Но даже и в этой в самом деле проблемной - области работа идет» [Юзефович, 2019].

В течение XIX-XX вв. отечественные журналы успешно играют такую же роль, как и литературные кружки и салоны карамзинской и пушкинской эпох. Вокруг редакций, внутри них происходит средоточие творческих интеллектуальных сил нации, создается область высокого духовного напряжения, где искусство напрямую сопрягается $c$ «художественным бытом» в тыняновской интерпретации этого явления. Недаром хронотоп «толстого» журнала поразительно совпадает с выделенным в работах М.М. Бахтина хронотопом «гостиная-салон», где происходит «сплетение исторического и общественно-публичного с частным и даже сугубо приватным... исторического ряда с бытовым и биографическим. Здесь сгущены, сконцентрированы наглядно-зримые приметы как исторического времени, так и времени биографического и бытового, и в то же время они теснейшим образом переплетены друг с другом, слиты в единые приметы эпохи. Эпоха становится наглядно-зримой и сюжетно-зримой» [Бахтин, 2000, с. 181].

Самим фактом повседневной постоянной работы внутри редакций и в процессе общения литераторов разных профессиональных специализаций с коллективами коллег журналы воссоздают среду, откуда в ходе литературной эволючии в словесность вливаются неизвестные ранее в искусстве художественные формы, где в ходе бытового общения и профессиональных обсуждений идет непрерывный процесс кристаллизаичи новых образов, идей, мировоззренческих матриц и ценностных установок.

Множество примеров того, как это происходило, можно найти в дневниковых записях А.Т. Твардовского «Из рабочих тетрадей (19531960)» (Знамя. 1987. № 7-9), в его «Рабочих тетрадях 60-х» (Знамя. 2000. № 6, 7, 9, 11, 12), в «Но- 
вомирском дневнике» А.И. Кондратовича (1991), в «Берегах культуры» В.Я. Лакшина (1994) о «Новом мире», в статьях и дневниках эпохи перестройки С.Ю. Куняева о «Нашем современнике» (1990), в мемуарном романе Н.Б. Ивановой «Ветер и песок: Роман с литературой в кратком изложении» (Знамя. 2015. № 3, 10) и ее же «романе-комментарии с ненаучными приложениями» «Такова литературная жизнь» (2017) - о «Знамени» и нетолько, в воспоминаниях Е. Мовчан «Моя “Дружба народов”: от оттепели до перестройки» (Дружба народов. 2019. № 3).

Так, Елена Мовчан, многолетний редактор книжного приложения к журналу, рассказывает, как кипела в период оттепели начала 1960-х гг. редакционная жизнь, когда границы между литературой и событиями, происходившими в стране, были слиты в единый бурный поток. В «Юность», где публиковались стихи Е. Евтушенко, Б. Ахмадулиной, А. Вознесенского, молодых сотрудников «Дружбы народов» приглашали «послушать интересные дискуссии, или молодых поэтов, или Юлия Кима и Юрия Коваля с их озорными песенками на якобы исторические темы» [Мовчан, 2019, c. 214]. А в редакцию «Дружбы народов» постоянно заходили писатели и переводчики из республик, разных российских городов, Москвы, «приносили свои произведения и беседовали с редакторами о литературе и жизни, некоторые заглядывали и в корректорскую поблагодарить нас за хорошую работу. <... Иногда утром... заглядывал Ираклий Андроников... и рассказывал нам свои замечательные истории. < ...> На праздники обычно приходили гости - авторы. Поэты иногда читали стихи, но больше просто разговаривали и много шутили. Приходил остроумный и обаятельный Михаил Светлов. <...> Смеляков, в противоположность Светлову, был всегда угрюм и мрачен... часто распекал авторов за неудачную рифму или за не понравившийся ему перевод» [Мовчан, 2019, с. 216-217].

«Литературный быт» способствует сплочению содружества единомышленников, что плодотворно и для литературы, и для создающих ее людей, и для читателей. В XIX в. во многом благодаря коллегиальной редакционной деятельности внутри литературных журналов происходила концептуализация художественных школ, на что не раз в своих ра- ботах указывал В.Б. Смирнов. В течение $\mathrm{XX}$ столетия журналы активно участвовали в формировании преимущественно идейномировоззренческих направлений отечественной словесности. Поэтому далеко не случайна приверженность писателя, критика «своему» журналу: И. Роднянской и В. Богомолова - «Новому миру», Л. Анненского и Б. Окуджавы - «Дружбе народов», где была опубликована вся проза поэтов. Елена Мовчан вспоминает, как предложила Валентину Распутину издать у них книгу и услышала в ответ решительное: «Нет, не могу, я печатаюсь только в "Нашем современнике"» [Мовчан, 2019, с. 224]

Представляется, что, когда каждый из современных журналов определится типологически и функционально, это писательское ощущение «своего» журнала возвратится. А значит, оно вернется и к читателю.

\section{Социокультурная миссия «толстого» журнала}

Несмотря на широкий круг полномочий в области литературы, отечественный «толстый» журнал всегда продуцировал и публицистический дискурс в его общественно-политическом, культурологическом, научно-популярном, социологическом изводах. В течение почти двух столетий это позволяло российскому журналу не просто нести читателю универсальное знание, но и эффективно участвовать в формировании общественного мнения и силовых линий идеологического поля. Исчерпал ли журнал свой публицистический и идеологический ресурс? М.О. Чудакова в постперестроечный период нашей истории отмечала, что ежемесячник имеет право на существование, если будет «всеми силами, оглядываясь на живую жизнь общества, стремиться быть обществу полезным» [Чудакова, 2000].

Будущее «толстых» журналов исследователь обусловливала тем, что в настоящий период российской истории наряду с традиционной просветительской функцией они призваны осуществлять более глобальную мировоззренческую миссию. Их главная цель всесторонний (интеллектуальный, философский, политический) анализ жизни России в трагически противоречивом XX веке. 
Современная общественно-политическая обстановка также требует не только беглой газетной строки, но и вдумчивого осмысления в неравнодушной журнальной публицистике. Именно ее, к сожалению, остро не хватает даже во многих столичных журналах, где преобладает культурологическая составляющая публицистического дискурса. В этом, на наш взгляд, одна из причин падения читательского интереса к «толстым» журналам.

Между тем их уникальный контекст и универсальная структура позволяют решать сложнейшую задачу по глубокому и многофакторному анализу реальности. «Органическое сочетание искусствоведческой и социальной информации, эстетической и идеологической проблематики, то есть одновременное функционирование в едином смысловом и текстовом пространстве художественного и публицистического дискурсов, дает возможность своевременно вводить в общественное сознание актуальные темы, новый эстетический, социальный, научный, нравственный опыт, увлекательно и убедительно говорить с читателями не только об искусстве, но и об окружающей их и постоянно меняющейся действительности, в том числе общественной, идеологической, политико-экономической» [Шильникова, 2011, с. 253-254].

Исторический опыт отечественных журналов свидетельствует о том, что именно они часто формировали в русском обществе информационную повестку дня, осуществляли прочедуру включения в дискуссию самых разных слоев населения, фокусируя общественное внимание на важнейших вопросах национального развития. Декабристы в своих изданиях инициировали полемику о народности и национальных основах культуры; шестидесятники и народники - о путях проведения реформы по отмене крепостного права и ее последствиях; в «толстых» журналах эпохи перестройки шли ожесточенные споры о восточной или западной ориентации России и новом экономическом укладе.

Некоторые журналы начинают откликаться на этот запрос, что неизбежно ведет к значительному расширению социально-публицистического дискурса издания. Из современных ежемесячников не намерен «отказываться ни от ясного обнаружения своих мировоззренчес- ких и... идеологических позиций, ни от пристального внимания к процессам, что идут внутри российского общества» [Чупринин, 2014] журнал «Знамя», для которого важнейшим компонентом публицистического дискурса остается очеркистика и аналитика. Главный редактор «Иностранной литературы» Александр Ливергант в 2015 г. отмечал, что журнал не просто активно публикует документалистику разных жанров (дневники, мемуары, путевые очерки, документальные романы), но вопреки традиционной структуре «толстого» журнала, порою номер именно с нее начинается, а замыкается художественной литературой.

«Новый мир», напротив, объявляет основным ориентиром для своей редакционной политики ряд принципов, которые отчасти противоречат друг другу: респектабельность, сочетание художественной новизны с интеллектуальной основательностью и даже своего рода академизмом, демократизм, консерватизм и историзм [История журнала]. В журнальном контексте это находит воплощение в постоянном обращении к прошлому, публикации значительного количества исторических, архивных материалов, что деформирует традиционный типологический алгоритм «толстого» журнала как органа СМИ. Нарушается феноменологическая целостность контекста, так как его содержание перестает корреспондировать с названием и историческим прошлым издания как заметного явления российской культуры.

Российские «толстые» журналы всегда принимали участие в решении таких социально значимых задач, как повышение уровня общекультурной компетентности российских читателей, организация их досуга, расширение кругозора. Для реализации функций образовательно-просветительского и рекреативного плана отечественные журналы в процессе своей эволюции выработали специальные механизмы и коммуникативные стратегии.

1. Популяризация творчества писателей и книг определенной направленности, самого процесса чтения как одного из путей самообразования личности с помощью литературнокритических текстов популяризаторского и аксиологического типа. Такова, например, peкомендательная колонка «Пестрая лента» руб- 
рики «Гуттенберг» Натальи Ивановой в «Знамени», представляющая собой аннотированные списки книг для чтения, отобранных квалифицированным знатоком и ценителем современной словесности.

2. Обязательное наличие в журнальном контексте мобильного библиографического отдела, где регулярно публикуются критические тексты информационных жанров (рецензии «газетного» типа, аннотации, заметки, полемические реплики), которые выполняют рекламно-справочные функции, а также в своей совокупности (например, годовой) воссоздают в сознании читателей виртуальные иенностные литературные иерархии.

3. Активное использование журнальных паратекстов в жанровых формах, которые корреспондируют с литературно-критическим дискурсом. Среди них - различные варианты комментариев, предисловий и послесловий, вступлений к художественным текстам (вступление-рекомендация, вступление-рецензия, вступление-биография, вступление-литературный портрет писателя, вступление-обзор). Журнальные паратексты, помимо информирования и просвещения читателей, расширения их кругозора, косвенно или напрямую направляют читательское восприятие, настраивают его на определенную аксиологическую волну, формируя отношение к автору, его творчеству и самому журналу.

В настоящее время все более востребованными у читателей становятся визуальные паратексты. Например, «вклейка» в 3-м номере за 2019 г. в «Дружбе народов», посвященная 80-летию журнала, где его история представлена в виде фотогалереи из личных архивов сотрудников издания.

4. Наличие театральных и др. рубрик по искусству, существующих с начала издания «толстых» журналов. Многие из современных изданий, в соответствии с тенденциями развития искусства, знакомят читателей с яркими знаковыми событиями, происходящими в мире музыки, выставочной сфере, архитектуре, графике, живописи, кинематографе, области Рулинета (статьи С. Костырко из «Нового мира») или литературной блогосфере (публикации 2019 г. О. Брейнингер в «Дружбе народов»).

5. Использование потенциала «ученой критики» (термин В.Г. Белинского), являющей- ся традиционным компонентом журнального контекста. Ее цель - ориентация читателей в безбрежном море современной книжной продукции, ценностный отбор и рекомендация читателям по самым разным отраслям знаний от философии и математики до биологии и педагогики, естествознания и истории. Например, раздел «Попутное чтение» С. Чупринина в «Знамени».

6. Издание журналом книжных приложений. В советский период такой опыт был у журнала «Огонек», где в качестве книжных приложений огромными тиражами выходили собрания сочинений русской и зарубежной классики. «Библиотека “Дружбы народов"» специализировалась на произведениях современных писателей, прежде всего «своих» авторов. Это не только привлекало к ежемесячнику достойных и популярных литераторов, но и поддерживало интерес аудитории к самому журнальному изданию.

Некоторые из современных журналов развивают традицию книжных «приложений», экспериментируя с их форматами. Таким образом периодическое издание выходит за контуры журнального поля, что в перспективе может повысить его авторитет и расширить аудиторную базу. В 2010 г. в «Урале» появилась рубрика «Детская», где публиковались лучшие тексты современной детской литературы. Через пять лет она переросла в регулярно выходящий при редакции альманах для семейного чтения, имеющий на сайте журнала свою страницу. Литературный журнал «Носорог», основанный в 2014 г., через четыре года расширил свою издательскую деятельность за счет одноименного издательства. По словам редакции, оно продолжает политику журнала по знакомству читателей с крупными прозаическими текстами, которым тесно в журнальных рамках. В 2000 г. журнал «Иностранная литература» стал учредителем издательства «Иностранка», которое занимается в основном современной переводной литературой и работает в тесном сотрудничестве с журналом.

\section{Заключение}

Полифункциональность - один из ценнейших типологических признаков отечественных 
литературно-художественных журналов. В течение длительного периода развития отечественной журналистики, культуры, истории именно это качество во многом обеспечивало устойчивость данного типа СМИ. Одновременно полифункциональность является залогом дальнейшей эволюции литературнохудожественного журнала как типа издания.

Большинство современных литературнохудожественных журналов декларируют стремление сохранить структурно-содержательную типологическую матрицу универсального русского ежемесячника и обусловленную ею функциональную парадигму. Однако в полном объеме функциональный потенциал изданий подобного типа не реализуется, что обусловлено комплексом объективных и субъективных факторов.

Среди субъективных факторов, создающих в современном журнальном поле «функциональную энтропию», следует назвать отсутствие у редакций должного внимания к типологическому определению изданий. Непродуктивно игнорировать тот факт, что журналы «литературно-художественный», «литературно-публицистический», «литературный и общественно-политический» - это разные по функциональной направленности, структуре, содержанию, составу целевой аудитории издания. Между тем их руководители главной и практически единственной причиной затянувшегося журнального кризиса считают недостаток финансирования и отсутствие помощи со стороны государства, несмотря на то, что многие из журналов давно являются собственностью коллектива.

К объективным факторам можно отнести новые экономические и технологические реалии, в которых оказалась система отечественных и мировых медиа, а также последовавшие за ними трансформации всей коммуникативной системы, в том числе формирование иных качества субъектов и форм литературно-художественной коммуникации.

В сфере литературной журналистики это ознаменовалось возникновением разнообразных сетевых версий литературно-художественных изданий, типологический профиль которых находится в стадии становления и потому не до конца ясен. Отсюда спорное мнение традиционных изданий, что переход журналов в элек- тронный формат разрушает единство литературно-журнального поля и является одной из причин его кризисного состояния.

Представляется, что будущее литературно-художественных журналов в том, чтобы стать полноправной частью новой информационной реальности и системы новых медиа. Важно, чтобы этот процесс сопровождался конкретизацией каждым изданием своего типологического профиля (миссии, цели, задач, целевой аудитории и того, что она, публика, определяет), своего сектора художественного поля, качества критического, публицистического дискурсов и способов их репрезентации, структурных особенностей, авторского состава, композиционно-графической модели, направлений внежурнальной социокультурной деятельности.

\section{СПИСОК ЛИТЕРАТУРЫ}

Анисимова Т. В., Ярова И. В., 2011. Реклама в издательском деле. Ижевск : КнигоГрад. 199 с.

Бак Д., 2015. Журнальная Россия. История русской литературы XX века. Круглый стол. 7 июля 2015 г. URL: http://literratura.org/publicism/1371tolstye-zhurnaly-nastoyaschee-bez-buduschego. $\mathrm{html}$ (дата обращения: 03.10.2018).

Барметова И., 2017. Дело «Октября». Почему погибают литературные журналы. Интервью с главным редактором журнала «Октябрь» Ириной Барметовой // Русский репортер. № 9 (426). C. 20-21.

Бахтин М. М., 2000. Эпос и роман. СПб. : Азбука. $304 \mathrm{c}$.

Беляков С., 2015. «Толстые» журналы: три вопроса редакторам // Знамя. № 1. URL: http://znamlit. ru/publication.php?id=5776 (дата обращения: 24.04.2017).

Василевский А., 2005. Юбилей в рабочем порядке. Беседа А. Василевского с корреспондентом газеты «Ex libris НГ» Александром Вознесенским 21 января 2005 г. URL: http://magazines. russ.ru/novyi_mi/redkol/vas/interv80.html. (дата обращения: 15.05.2017).

Дубин Б., 2010. О чтении и нечтении сегодня // Вестник общественного мнения. № 3 (105). С. 66-74.

Иванова Н., 2015. «Непрерывное производство». Десять тезисов о судьбе журнального дела // Знамя. № 9. URL: https://magazines.gorky. media/znamia/2015/9/nepreryvnoe-proizvodstvo. html (дата обращения: 23.04.2019).

История журнала «Новый мир». URL: http://www. nm1925.ru/AboutMagazine/14/Default.aspx (дата обращения: 23.04.2019). 
«Толстяки на Урале», 2016 / подгот. А. Вдовин, Н. Колтышева // Урал. № 2. URL: http:// magazines.russ.ru/ural/2016/2/tolstyaki-naurale.html (дата обращения: 14.12.2018).

Лукьянин В., 2005. Литературные итоги - 2004, обсуждают: Леонид Быков, Валентин Лукьянин. Анкета журнала «Урал» // Урал. № 3. URL: http://magazines.russ.ru/ural/2005/3 (дата обращения: 10.12.2017).

Мовчан Е., 2019. Моя «Дружба народов»: от оттепели до перестройки // Дружба народов. № 3. С. 214-228.

Подлубнова Ю., 2019. Критика: последний призыв // Знамя. № 1. URL: http://znamlit.ru/ publication. php?id=7149 (дата обращения: 23.04.2019).

Чудакова М., 2000. На пороге новых дней. Андрей Василевский беседует с М.О. Чудаковой // Новый мир. № 1. URL: https://magazines.gorky. media/novyi_mi/2000/1/na-poroge-novyhdnej.html (дата обращения: 23.04.2019).

Чупринин С., 2014. «Знамя» в 2014 году: декларация о намерениях // Знамя. № 1. URL: http:// magazines.russ.ru/znamia/2014/1/1ch.html) (дата обращения: 01.04.2016).

Шильникова О. Г., 2011. Литературная критика в журнальном контексте рубежа XX-XXI веков: принципы функционирования и качественного взаимодействия текстов. Волгоград : Изд-во ВолГУ. 284 с.

Юзефович Г., 2019. Критика: последний призыв // Знамя. № 1. URL: http://znamlit.ru/publication. php?id=7149 (дата обращения: 23.04.2019).

\section{REFERENCES}

Anisimova T.V., Yarova I.V., 2011. Reklama $v$ izdatelskom dele [Advertising in Publishing]. Izhevsk, KnigoGrad Publ. 199 p.

Bak D., 2015. Zhurnalnaya Rossiya. Istoriya russkoy literatury XX veka. Kruglyy stol. 7 iyulya $2015 \mathrm{~g}$. [Magazine Russia. History of Russian Literature of the $20^{\text {th }}$ Century. Round Table. July 7, 2015]. URL: http://literratura.org/publicism/1371-tolstyezhurnaly-nastoyaschee-bez buduschego.html (accessed 3 October 2018).

Barmetova I., 2017. Delo «Oktyabrya». Pochemu pogibayut literaturnye zhurnaly. Intervyu s glavnym redaktorom zhurnala «Oktyabr» Irinoy Barmetovoy ["October” Case. Why Literary Magazines Die. Interview with Editor-in-Chief of "October" Magazine Irina Barmetova]. Russkiy reporter, no. 9 (426), pp. 20-21.

Bakhtin M.M., 2000. Epos i roman [Epic and Novel]. Saint Petersburg, Azbuka Publ. 304 p.
Belyakov S., 2015. «Tolstye» zhurnaly: tri voprosa redaktoram ["Thick" Magazines: Three Questions to Editors].Znamya, no. 1. URL: http:// znamlit.ru/publication.php?id=5776 (accessed 24 April 2017).

Vasilevskiy A., 2005. Yubiley v rabochem poryadke. Beseda A. Vasilevskogo s korrespondentom gazety "Ekh libris NG» Aleksandrom Voznesenskim 21 yanvarya $2005 \mathrm{~g}$. [Anniversary in Working Order. Conversation of A. Vasilevskiy with Correspondent of "Ex Libris NG" Newspaper Aleksander Voznesensky on January 21, 2005]. URL: http://magazines. russ. EN/novyi_mi/redkol/vas/interv $80 . \mathrm{html}$ (accessed 15 May 2017).

Dubin B., 2010. O chtenii i nechtenii segodnya [On Reading and Non-Reading Today]. Vestnik obshchestvennogo mneniya [Russian Public Opinion], no. 3 (105), pp. 66-74.

Ivanova N., 2015. «Nepreryvnoe proizvodstvo». Desyat tezisov o sudbe zhurnalnogo dela ["Continuous Production". Ten Theses About the Fate of the Magazine Business]. Znamya, no. 9. URL: https://magazines.gorky.media/ znamia/2015/9/nepreryvnoe-proizvodstvo.html (accessed 23 April 2019).

Istoriya zhurnala «Novyy mir», 2019. [History of "New World" Journal]. URL: http://www.nm1925.ru/ AboutMagazine/14/Default.aspx (accessed 23 April 2019).

«Tolstyaki na Urale», 2016. [The "Fat in the Urals"]. Ural, no. 2. URL: http://magazines. russ.ru/ural/ 2016/2/tolstyaki-na-urale.html (accessed 14 December 2018).

Lukyanin V., 2005. Literaturnye itogi - 2004, obsuzhdayut: Leonid Bykov, Valentin Lukyanin. Anketa zhurnala «Ural» [Literary End of 2004, Discuss: Leonid Bykov, Valentin Lukyanin. The Questionnaire of "Ural" Journal]. Ural, no. 3. URL: http://magazines.russ.ru/ural/2005/3 (accessed 10 December 2017).

Movchan E., 2019. Moya «Druzhba narodov»: ot ottepeli do perestroyki [My "Friendship of Peoples": From Thaw to Perestroyka]. Druzhba narodov, no. 3, pp. 214-228.

Podlubnova Yu., 2019. Kritika: posledniy prizyv [Criticism: The Latest Call]. Znamya, no. 1. URL: http://znamlit.ru/publication.php?id=7149 (accessed 23 April 2019).

Chudakova M., 2000. Na poroge novykh dney. Andrey Vasilevskiy beseduet s M.O. Chudakovoy [On the Threshold of New Days. Andrey Vasilevsky Talks with M.O. Chudakova]. Novyy mir, no. 1. URL: https://magazines.gorky.media/novyi_mi/ 2000/1/na-poroge-novyh-dnej.html (accessed 23 April 2019). 
Chuprinin S., 2014. "Znamya» v 2014 godu: deklaratsiya o namereniyakh ["Znamya" in 2014: Declaration of Intentions]. Znamya, no. 1. URL: http://magazines.russ.ru/znamia/2014/1/1ch.html (accessed 1 April 2016).

Shilnikova O.G., 2011. Literaturnaya kritika $v$ zhurnalnom kontekste rubezha $X X-X X I$ vekov: printsipy funktsionirovaniya $i$ kachestvennogo vzaimodeystviya tekstov [Literary Criticism in the Journal Context of the Turn of $20^{\text {th }}-21^{\text {st }}$ Centuries: Principles of Functioning and Qualitative Interaction of Texts]. Volgograd, Izd-vo VolGU. 284 p.

Yuzefovich G., 2019. Kritika: posledniy prizyv [Criticism: The Latest Call]. Znamya, no. 1. URL: http://znamlit.ru/publication.php?id=7149 (accessed 23 April 2019).

\section{Information about the Authors}

Olga G. Shilnikova, Doctor of Sciences (Philology), Professor, Department of Russian Philology and Journalism, Volgograd State University, Prosp. Universitetsky, 100, 400062 Volgograd, Russia, glossa2@rambler.ru, https://orcid.org/0000-0002-7857-3648

Galina S. Belolipskaya, Candidate of Sciences (Philology), Associate Professor, Head of the Department of Theory and History of Journalism, Astrakhan State University, Tatishcheva St., 20a, 414056 Astrakhan, Russia, asu@asu.edu.ru, gbelolipskaya@yandex.ru, https://orcid.org/0000-0003-0133-5729

\section{Информация об авторах}

Ольга Геннадьевна Шильникова, доктор филологических наук, профессор кафедры русской филологии и журналистики, Волгоградский государственный университет, просп. Университетский, 100, 400062 г. Волгоград, Россия, glossa2@rambler.ru, https://orcid.org/0000-0002-7857-3648

Галина Сергеевна Белолипская, кандидат филологических наук, доцент, заведующая кафедрой теории и истории журналистики, Астраханский государственный университет, ул. Татищева, 20a, 414056 г. Астрахань, Россия, asu@asu.edu.ru, gbelolipskaya@yandex.ru, https://orcid.org/0000-0003-0133-5729 